Citation: Kavak D. G. \& A ğırbaş İ. \& Balbay Y.\& Avcı K. (2017), Cost Analysis Of Coronary Interventions: Transradial Or Transfemoral?, BMIJ (2017) 5(3): 640-653 doi: $\underline{\text { http://dx.doi.org/bmij.v5i3.148 }}$

\title{
COST ANALYSIS OF CORONARY INTERVENTIONS: TRANSRADIAL OR TRANSFEMORAL?
}

\author{
Demet GOKMEN KAVAK ${ }^{1}$ \\ İsmail AĞIRBAŞ2 \\ Yücel BALBAY ${ }^{3}$ \\ Keziban A VCI ${ }^{4}$
}

\author{
Received (Başvuru Tarihi): 27/09/2017 \\ Accepted (Kabul Tarihi):02/11/2017
}

Published Date (Yayın Tarihi): 20/12/2017

\begin{abstract}
The purpose of this research is to conduct cost minimisation analysis of coronary angiography interventions with Transradial (TRA) and Transfemoral (TFA) approach. Thus, operators will be guided in relation with intervention selection and cardiovascular area on the subject matter will be enriched which is quite inadequate with a cost analysis sample. The research has been conducted by evaluating and examining of data of the patients who had coronary angiography. Population of the research consists of angiography interventions in the scope of the research carried out within the year of 2013 in a Cardiology Clinic of a tertiary hospital. Patient records were randomly selected. At the end of the research, the findings have revealed that the costs of TRA and TFA have been respectively Turkish Liras (TRY)746,214 and TRY 710,040. The cost of TRA approach is higher than TFA approach. On the other hand, experts' opinion is that TRA approach is a more reliable alternative compared to TFA approach. In the selection process of the approach to be used by the operators, it would be beneficial for the patients when both the cost and results of the intervention are considered simultaneously.
\end{abstract}

Keywords: Cost Analysis, Cost Minimization, Transradial, Transfemoral, Coronary Intervention

JEL Codes: I1 1, M21

\section{KORONER GIRIŞiMLERİN MALIYET ANALIZi: TRANSRADIAL Mí TRANSFEMORAL MI?}

ÖZ

Araştırmanın amacı, Transradial (TRA) ve Transfemoral (TFA) yaklaşım ile yapılan koroner anjiyografi işlemlerinin maliyet minimizasyon analizinin yapılmasıdır. Böylece, uygulayıcılara işlem tercihi konusunda rehberlik sağlanacak aynı zamanda kardiyovasküler alanda oldukça yetersiz olan bir maliyet analizi örneği kazandırılacaktır. Araştırma retrospektif olarak koroner anjiografi işlemi yapılan hastalara ait verilerin incelenmesi ve değerlendirilmesi yoluyla yürütülmüşı̈̈r. Araştırmanın evrenini üçüncü basamak bir hastanenin

\footnotetext{
1 Türkiye Să̆lık Enstitüleri Başkanlı̆̆ı, Uzman kavakdemet@gmail.com

${ }^{2}$ Ankara Üniversitesi, SağlıkBilimleri Fakültesi, Prof.Dr. ismail.agirbas@ankara.edu.tr

${ }^{3}$ Sağlık Bilimleri Üniversitesi, Ankara Y.I.S.U.A.M., Prof.Dr. vücelbalbav1@gmail.com

${ }^{4}$ Türkiye Sağlık Enstitüleri Başkanlığı, Yrd.Doç.Dr. kezibanavcil@gmail.com
}

http://orcid.org/0000-0002-0760-9551

http://orcid.org/0000-0002-1664-5159

http://orcid.org/0000-0001-6629-971X

http://orcid.org/0000-0003-0998-9583 
kardiyoloji kliniğinde 2013 yılı içinde yapılan anjiografi işlemleri oluşturmaktadır. Randomize seçilen hasta kayıtları araştırma kapsamına alınmıştır. Araştırma sonucunda TRA maliyeti 746,214 TL, TFA maliyeti 710,04 TL olarak bulunmuştur. TRA yaklaşımının maliyeti TFA yaklaşımından daha yüksektir. Buna karşılık, uzman görüşleri, TRA yaklaşımının TFA yaklaşımına göre daha güvenli bir alternatifolduğu yönündedir. Uygulayıcılar tarafindan, hangi yaklaşım türünün seçileceği belirlenirken, işlemin parasal maliyeti ve işlemin sonuçlarının birlikte düşünülmesi, hastalar açısından yararlı olacaktır.

Anahtar Kelimeler: Maliyet Analizi, Maliyet Minimizasyonu, Transradial, Transfemoral, Koroner Girişim

JEL Kodları: I1 1, M21

\section{INTRODUCTION}

Coronary angiography is a diagnosis method applied by displaying the coronary arteries after injection of radiopaque contrast matter in the vein in order to display coronary anatomy, assess treatment options, and estimate the prognosis in coronary artery disease (KAH). Owing to the new methods used in coronary angiography and the experience gained, the rates of complications have significantly decreased and hospitalization periods have been shortened (Noto et al, 1991:7, TKD, 2005).

Transradial (TRA) and Transfemoral (TFA) approaches are preliminary techniques applied by the relevant specialist in coronary angiography intervention (TKD, 2005). Transfemoral approach is a method which is suitable for cardiologists in many aspects and is very commonly used (Louvard, Lefevre and Morice, 1997; 467). Different approaches from transfemoral approach have been researched in order to decrease the patient complications such as bleeding complications in vein entrance, observation of long periods and the requirement of bed rest and increase the life quality in the diagnostic and interventional operations due to patient diseases (Aktürk et al, 2014:140).

TRA is considered as a coronary angiography approach which is alternative gradually preferred more frequently compared to TFA for reasons such as increase in patient comfort, shortening in hospitalization periods, decrease in hospital costs, and providing serious clinical benefit by decreasing the complications on the artery entrance site (Bertrand et al, 2010: 1022, Caputo et al, 2011:823).

TRA and TFA are two approaches which create the same effect in terms of the results of the intervention but differentiate in terms of costs. In the literature, there is no study in which the financial costs of these two processes are compared.

In this study, it is aimed that cost minimisation analysis of coronary angiography interventions made with TFA and TRA approaches are conducted and the least costly angiography approach is determined for the decision makers. Cost minimisation is the economic assessment method based on the principle in which the least costly health program is 
selected in cases where alternative health programs result in the same or similar results (Ağırbaş, 2014:426, Çelik, 2013:280). As the result of cost analysis made with this technique, if intervention $\mathrm{A}$ is more costly than intervention $\mathrm{B}$ and produces the same result, decision must be made for intervention $B$ in this case (Tatar, 2013:339).

\section{METHODS}

The research was conducted in a catheter laboratory of a tertiary hospital. The files of approximately 400 patients to whom coronary angiographic intervention has been applied between January and June 2013 have been retrospectively examined. 110 patient files not having additional cost elements which can affect the intervention cost in terms of TRA or TFA such as angiography+stent placement, angiography+balloon angioplasty, left heart ventriculography etc. and to whom diagnostic angiography has been applied with the suspicion of Coronary Artery Disease (CAD) are in the scope of the study randomly selected to have an equal number of patients in terms of TRA and TFA approaches (55 TFA and 55 TRA). Files taken into the scope of sample are randomly selected with the method of stratified sampling. Regarding the direct costs of TFA and TRA in terms of patients, patient invoice data in Hospital Information Management System (HBYS) has been examined. Expense items have been consolidated Excel on the basis of interventions and patients. Indirect cost elements which affect the intervention costs have been assessed based on the cost studies made by the hospital in 2013. Mann-Whitney $U$ test has been conducted by using SPSS 20 packaged software for descriptive statistics and assessment of significance level of the difference between two groups.

\section{RESULTS}

\subsection{Demographic and Clinical Characteristics}

52 of the patients taken into the scope of the study were female and 52 of them were male. $43.6 \%$ of the patients $(n=48)$ were within the age group of 65 or over and there were a few patients under $35(\mathrm{n}=3) .99,1 \%$ of the patients had Social Security Institution (SSI) insurance (Table 1). 
Table 1. Distribution of Patients by Gender, Age and Social Security Status

\begin{tabular}{|l|l|l|l|}
\hline \multirow{2}{*}{ Variable } & Number & \% \\
\hline \multirow{3}{*}{ Gender } & Male & $\mathbf{5 2}$ & 47,2 \\
\cline { 2 - 4 } & Female & $\mathbf{5 8}$ & 52,8 \\
\hline \multirow{5}{*}{ Age } & $18-24$ & $\mathbf{1}$ & 0,9 \\
\cline { 2 - 4 } & $25-34$ & $\mathbf{2}$ & 1,8 \\
\cline { 2 - 4 } & $35-44$ & 3 & 2,7 \\
\cline { 2 - 4 } & $45-54$ & 23 & 20,9 \\
\cline { 2 - 4 } & $55-64$ & 33 & 30 \\
\cline { 2 - 4 } Social Security & $65+$ & 48 & $\mathbf{4 3 , 6}$ \\
\cline { 2 - 4 } & SSI & 109 & 99,1 \\
\hline \multirow{2}{*}{ TOTAL } & $\mathbf{1}$ & $\mathbf{0 , 9}$ \\
\hline & $\mathbf{1 1 0}$ & \\
\hline
\end{tabular}

Considering the distributions of coronary angiography intervention type applied to the patients by gender, age, and social security status;

- Intervention was applied with TRA approach in 52,7\% of male patients, while TFA approach was selected in $58,1 \%$ of female patients.

- While TRA approach was applied in all patients under 45, TFA approach was preferred more in age group of 45-54 and over $65(27,2 \% ; 45,4 \%)$.

- All the patients to whom TFA approach was applied have SSI insurance (Table 2)

Table 2. Distribution of The Intervention Type Applied by Gender, Age and Social Security Status

\begin{tabular}{|c|c|c|c|c|c|}
\hline \multirow{3}{*}{ Variable } & & \multicolumn{4}{|c|}{ Invention Type } \\
\hline & & \multicolumn{2}{|c|}{$\begin{array}{l}\text { TRA } \\
(n=55)\end{array}$} & \multicolumn{2}{|c|}{$\begin{array}{l}\text { TFA } \\
(n=55)\end{array}$} \\
\hline & & No & $\%$ & No & $\%$ \\
\hline \multirow{2}{*}{ Gender } & Male & 29 & 52,7 & 23 & 41,8 \\
\hline & Female & 26 & 47,2 & 32 & 58,1 \\
\hline \multirow{6}{*}{ Age } & $18-24$ & 1 & 1,8 & & \\
\hline & $25-34$ & 2 & 3,6 & & \\
\hline & $35-44$ & 2 & 3,6 & 1 & 1,8 \\
\hline & $45-54$ & 8 & 14,54 & 15 & 27,2 \\
\hline & $55-64$ & 19 & 34,54 & 14 & 25,4 \\
\hline & $65+$ & 23 & 41,8 & 25 & 45,4 \\
\hline \multirow{2}{*}{$\begin{array}{l}\text { Social } \\
\text { Insurance }\end{array}$} & SSI & 54 & 98,2 & 55 & 100 \\
\hline & Paid & 1 & 1,8 & & \\
\hline & TOT & \multicolumn{4}{|c|}{110} \\
\hline
\end{tabular}


When examining the distributions of the patients by the reason of application to the hospital and diagnoses made during the outpatient examination conducted before the intervention;

- It was observed that $90,9 \%$ of the patients were diagnosed with Atherosclerotic Heart Disease, 61,8\% with Hyperlipidemia, and 59\% with Essential Hypertension and some patients were diagnosed with chest pain unidentified with the rate of $95,4 \%$ in addition to one or some of these diagnoses or as a single diagnosis (Table 3).

Table 3. Distribution by Pre-Intervention Diagnoses

\begin{tabular}{|l|l|l|}
\hline Diagnosis & No (n=110) & \% \\
\hline Essential Hypertension & 59 & 53,6 \\
\hline Unidentified Chest Pain & 105 & 95,4 \\
\hline Atherosclerotic Heart Disease & 100 & $\mathbf{9 0 , 9}$ \\
\hline Hyperlipidemia & 68 & 61,8 \\
\hline Gastritis & 1 & 0,9 \\
\hline Heart Failure & 2 & 1,8 \\
\hline Gastroesophageal Reflux & 1 & 0,9 \\
\hline Atherosclerotic Cardiovascular Disease & 4 & 3,6 \\
\hline Supraventricular Tachycardia & 1 & 0,9 \\
\hline Unstable Angina & 1 & 0,9 \\
\hline Chronic Kidney Failure & 1 & 0,9 \\
\hline Atrial Fibrillation & 1 & 0,9 \\
\hline Pacemaker & 1 & 0,9 \\
\hline Dyspnoea & 1 & 0,9 \\
\hline
\end{tabular}

\subsection{Calculations for Intervention Costs}

According to the study data, elements affecting the cost in terms of TRA and TFA approaches are gathered under six titles. It has been detected as the result of the examinations of the invoices of the patients, elements directly affecting the cost are intervention expenses, expenses for consumables, and medicine expenses. According to the information obtained from the cost analysis made by the hospital in 2013, it is observed that outpatient examination labour costs, intervention team labour cost, and overhead costs are the elements indirectly affecting the costs in both TRA and TFA approaches. The direct costs of TFA and TRA was calculated by using patients' invoice data. Findings related to overheads and intervention costs for TRA and TFA are listed separately below.

\subsubsection{Transradial Coronary Angiography (TRA)}

In Table 4, elements affecting the coronary angiography intervention made with TRA approach are shown. According to the calculation results made based on each patient; 
- For each patient to whom coronary angiography intervention is applied with TRA approach the average intervention expense is TRY 255,04, expenses for consumables is TRY 115,83, medicine expense is TRY 73,84, outpatient examination labour cost is TRY 47,09, intervention team labour cost TRY 70,15, and overhead cost is TRY 184,25.

- Total intervention expense per patients who had coronary angiography intervention is made with TRA approach is TRY 746,214.

Table 4. Elements Affecting Coronary Angiography Intervention Cost Made With TRA Approach

\begin{tabular}{|l|r|}
\hline Elements Affecting the Cost & Amount (TRY) \\
\hline Intervention Expense & TRY 255,05 \\
\hline Expenses for Consumables & TRY 115,83 \\
\hline Medicine Expense & TRY 73,84 \\
\hline Outpatient Examination Labour Cost & TRY 47,09 \\
\hline Intervention Team & TRY 70,15 \\
\hline General Production Cost & TRY 184,25 \\
\hline Total Cost & TRY $\mathbf{7 4 6 , 2 1 4}$ \\
\hline
\end{tabular}

Considering the rational distributions of the elements affecting the costs in terms of TRA approach, it is seen that intervention expenses $(34,1 \%)$ and general production costs $(24,6 \%)$ affect the coronary angiography intervention costs with TRA approach more than the others. One of the important elements in the third place in terms of affecting the cost is expenses for consumables and this rate is calculated to be $15,5 \%$ (Graphic 1)

Graphic 1. Rational Distribution of Cost Elements For Coronary Angiography Intervention With TRA Approach

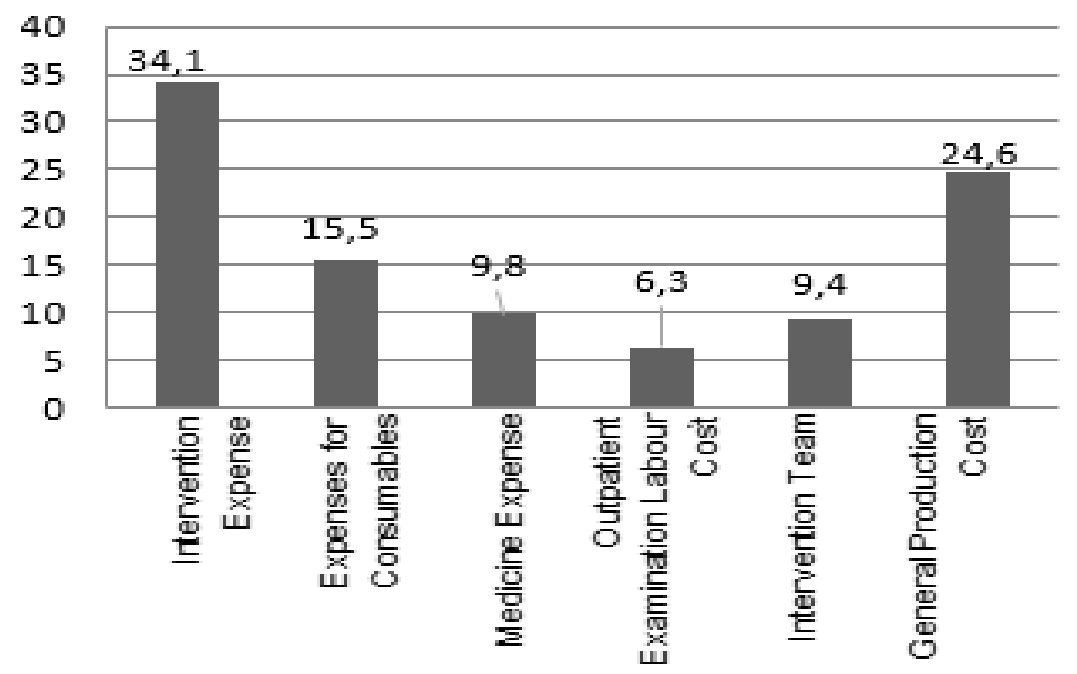




\subsubsection{Transfemoral Coronary Angiography (TFA)}

In Table 5, elements affecting the coronary angiography intervention made with TRA approach are shown. According to the calculation results made based on each patient;

- For each patient to whom coronary angiography intervention is applied with TRA approach the average intervention expense is TRY 261,94, expenses for consumables is TRY 75,11, medicine expense is TRY 71,49, outpatient examination labour cost is TRY 47,09, intervention team labour cost TRY 70,15, and general production cost is TRY 184,25 .

- Total intervention expense per patient to whom coronary angiography intervention is made with TRA approach is TRY 710,04.

Table 5. Elements Affecting Coronary Angiography Intervention Cost Made with TRA Approach

\begin{tabular}{|l|r|}
\hline Elements Affecting the Cost & Amount (TRY) \\
\hline Intervention Expense & TRY 261,94 \\
\hline Expenses for Consumables & TRY 75,11 \\
\hline Medicine Expense & TRY 71, 49 \\
\hline Outpatient Examination Labour Cost & TRY 47,09 \\
\hline Intervention Team & TRY 70,15 \\
\hline General Production Cost & TRY 184,25 \\
\hline Total Cost & TRY 710,04 \\
\hline
\end{tabular}

Considering the rational distributions of the elements affecting the costs in terms of TRA approach, it is seen that intervention expenses $(36,8 \%)$ and general production costs $(25,9 \%)$ affect the coronary angiography intervention costs with TRA approach more than the others. One of the important elements in the third place in terms of affecting the cost is expenses for consumables and this rate is calculated to be $15,5 \%$ (Graphic 2) 
Graphic 2. Rational Distribution of Cost Elements for Coronary Angiography Intervention with TRA Approach

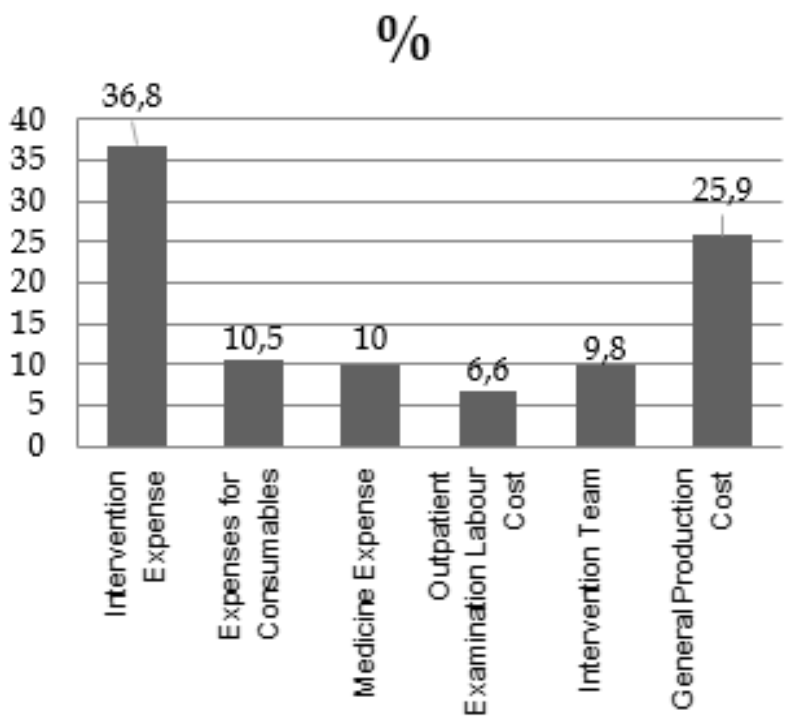

When elements affecting the cost are compared in terms of TRA and TFA, it is seen that although indirect cost elements are fixed, direct cost elements such as; expenses for consumables, intervention, and medicine are different in terms of both approach. While average TRA intervention cost per patient is TRY 746,214, total cost of TFA intervention is calculated to be TRY 710,04 (Table 6).

Table 6. Comparison of Elements Affecting The Cost in Terms of TRA and TFA

\begin{tabular}{|l|l|l|}
\cline { 2 - 3 } \multicolumn{1}{c|}{} & TRA & TFA \\
\hline Intervention Expense & TRY 255,05 & TRY 261,94 \\
\hline Expenses for Consumables & TRY 115,83 & TRY 75,11 \\
\hline Medicine Expenses & TRY 73,84 & TRY 71, 49 \\
\hline $\begin{array}{l}\text { Outpatient Examination Labour } \\
\text { Cost }\end{array}$ & TRY 47,09 & TRY 47,09 \\
\hline Intervention Team Labour Cost & TRY 70,15 & TRY 70,15 \\
\hline General Production Cost & TRY 184,25 & TRY 184,25 \\
\hline TOTAL (TRY) & TRY $\mathbf{7 4 6 , 2 1 4}$ & TRY 710,04 \\
\hline
\end{tabular}

\subsection{Expert Opinions}

Coronary Angiography is one in which coronary arteries are displayed in a radiological way with the invasive method by entering from any artery for diagnosis of coronary artery disease. It is gold standard for diagnosis of coronary artery disease. 
Alternative of this intervention is multi-slice Coronary BT angiography. However, when serious artery disease is detected in BT angiography, again coronary angiography is needed to verify the degree of the obstruction. Coronary Angiography intervention allows operations for treatment of coronary artery disease after diagnosis (such as balloon angioplasty, stenting) which is not possible in Coronary BT angiography.

In coronary angiography, selection of the entry point (decision of TRA or TFA intervention) is determined by the specialists by considering the elements such as suitability of artery diameter, patient comfort, early mobilization, complication risks etc. independent from patient choices. There is no difference between angiographies made with any method in terms of displays taken and interpretation in relation with coronary arteries once they are reached. The radial artery is more superficial, bleeding control is ensured more easily after angiography.

In angiography applied from hand ankle, complications depending on entrance point (bleeding, swelling) are little if any. If there is a known obstruction in abdomen or leg arteries of the patient, it is more suitable to choose radial artery in overweight persons especially in terms of abdomen and groin. On the other hand, radial artery is thinner and spasm probability is higher when compared to the femoral artery. It prevents reaching coronary arteries especially in slimmer persons. On the other hand, in women having thin hand ankle and thus radial artery, applying angiography through femoral artery is easier and healthier for both the patient and specialist.

While patients are mobilized shortly after the procedure in radial approach, hospitalization period of the patient on average in femoral approach is 4 hours. No companion is generally required for these patients.

Finally, results of the intervention are similar in both approaches of TRA and TFA and medical materials and consumables and the requirement to use multiple materials in some patients and the obligation to choose the catheter diameter used in interventions suitable with the artery diameter of the patient are the elements increasing the cost.

\subsection{Statistical Analyses}

According to Mann-Whitney U Test conducted in order to detect the significance level of the differences obtained in terms of TRA and TFA approaches;

- Variances are equal to each other and do not show normal distribution (Table 7).

- There is difference in terms of intervention expense, expenses of consumables, and medicine expenses between two approaches (Table 8) 
- There is no difference in terms of outpatient, labour, and general production costs between two approaches (Table 8)

- The difference in expenses of consumables regarding TRA and TFA approaches is statistically significant $(\mathrm{p}<0,05$ Table 8$)$.

- Although there is no difference between two approaches in terms of intervention expenses and medicine expenses, this difference is not statistically significant $(\mathrm{p}<0,05)$ (Table 8$)$.

Table 7. Homogeneity of Variances

\begin{tabular}{|l|r|r|r|r|}
\hline & \multicolumn{1}{|c|}{ Levene Statistics } & \multicolumn{1}{c|}{ df1 } & \multicolumn{1}{c|}{ df2 } & \multicolumn{1}{c|}{ Sig. } \\
\hline Intervention Expenses & 0,399 & 1 & 108 & 0,529 \\
\hline $\begin{array}{l}\text { Expenses for } \\
\text { Consumables }\end{array}$ & $\cdots$ & 1 & 108 & 0,05 \\
\hline Medicine Expenses & 3,283 & 1 & 108 & 0,073 \\
\hline Outpatient Expenses &. & 1 & &. \\
\hline Labour Cost &. & 1 & &. \\
\hline General Production Cost &. & 1 & &. \\
\hline Total Cost & $\mathbf{8 , 2 3 4}$ & $\mathbf{1}$ & $\mathbf{1 0 8}$ & $\mathbf{0 , 0 0 5}$ \\
\hline
\end{tabular}

Table 8.Statistical Analyses

\begin{tabular}{|l|l|l|l|l|}
\hline & $\begin{array}{l}\text { Mann- } \\
\text { Whitney U }\end{array}$ & $\begin{array}{l}\text { Wilcoxon } \\
\text { W }\end{array}$ & $\mathbf{Z}$ & $\begin{array}{l}\text { Asymp. Sig. } \\
\text { (2-tailed) }\end{array}$ \\
\hline $\begin{array}{l}\text { Intervention } \\
\text { Expenses }\end{array}$ & 1418,500 & 2958,500 &,- 596 &, 551 \\
\hline $\begin{array}{l}\text { Expenses for } \\
\text { Consumables }\end{array}$ & 653,000 & 2193,000 & $-5,138$ & $\mathbf{, 0 0 0}$ \\
\hline Medicine Expenses & 1444,000 & 2984,000 &,- 410 &, 681 \\
\hline Outpatient Expenses & 1512,500 & 3052,500 &, 000 & 1,000 \\
\hline Labour Cost & 1512,500 & 3052,500 &, 000 & 1,000 \\
\hline $\begin{array}{l}\text { General Production } \\
\text { Cost }\end{array}$ & 1512,500 & 3052,500 &, 000 & 1,000 \\
\hline Total Cost & 1218,000 & 2758,000 & $-1,761$ &, 078 \\
\hline
\end{tabular}

\section{DISCUSSION}

In this study, cost minimisation analysis for the costs of coronary angiography interventions with TFA and TRA approaches has been made. The study is the first one in which the costs of these two approaches are compared.

Transradial coronary angiography is an approach providing safer alternatives compared to femoral approach in Western societies, Chinese patients, and Japanese patients. On the other 
hand, technical complexity regarding the application procedure limits the use of this method (Yiğit et al, 2006:232).

Radial artery first was used in 1989 in interventional coronary artery interventions and is preferred more due to multiple advantages today. Radial artery using frequency has increased within a period of 20 years approximately (Kiemeneij and Laarman, 1993:173-178).

In literature, studies in which these two methods are compared in terms of the time of intervention, intervention technique (Balbay maneuver) (Ünal et al, 2016:10-13), time of entering the vein, the amount of contrast matter used, hospitalization period, number of catheters used, pain experienced during the intervention etc. are seen.

In the study of Agostoni et al.( 2004:349-356) in which clinical and interventional end points are compared with meta-analysis, 22 studies have been assessed and it has been observed that transradial intervention is a safer option compared to the transfemoral intervention. Although the analysis contains rather heterogeneous groups, the average intervention period is 35 minutes in the transradial group and 33.8 minutes in the transfemoral group, and floroscopy duration is 7.8 minutes in transfemoral group and 8.9 minutes in the radial group. Considering the failure rates in relation with the intervention, failure rates have been found to be $9.3 \%$ in femoral, and $10.6 \%$ in radial due to age of the patients which is over 80 . While complications of the intervention place are monitored only in three cases in radial, complication rates in femoral is $2.8 \%$.

In this study, according to the results of the assessment to see whether preference of interventions differ depending on the age groups, it is observed that TFA approach is preferred more in patients of 65 years or over $(45,5 \%)$. The reason of it may be that failure rate in femoral patient with advanced ages is lower compared to the radial. It may be said that findings obtained in the study of Agostoni et al (2004:349-356) have characteristics to support this finding.

Considering the methods depending on the age, parallel with the expert opinions, to use of femoral artery is easier and healthier for the specialist, and the female patients since radial intervention has been preferred more in female patients compared to male patients. Female patients have more slender structure compared to the male patients, and radial artery and hand ankles are thinner in female patients.

In the assessment made according to the social security status of the patients, it is observed that the majority of the patients have SSI insurance and TRA approach has been preferred in $92,7 \%$ of them. This case may be explained as follows; in the hospital in which the 
study has been conducted, there are two treatment services which are ambulatory treatment and inpatient treatment. Invoicing process of the interventions, tests, consumables for treatment, and medicine for patients are as follows: A patient having ambulatory treatment gets banderole from the department of information technologies before all inspections and tests and interventions made this way are directly invoiced. However, it is different and more complex for the patients having inpatient treatment. Consumables and medicine used for the patient, additional interventions applied on the patient, and tests before, during, and after any intervention are recorded on the documents in the patient file. Invoices are drawn up with the information entered on the central invoicing system in the secretarial and interventions are subjected to the application of bundle pricing. Intervention point of the P700810 "Selective Coronary Angiography" intervention is 699,83 in the ANNEX-2/C list of Healthcare Implementation Declaration of 2013 and intervention amount is TRY 415,00 when multiplied with the coefficient of $(0,593)$. When Training and Research Hospital is added, HPN price is determined to be TRY 456,50. Hospital invoices the amount of each patient to whom angiography is applied to Social Security Institution (through bundle pricing application to SSI) without distinguishing radial or femoral angiography. Although it is a more expensive option than the femoral approach, the choice of radial approach may be due to the fact that the reimbursement for patients with SSI is made easier than others.

When considering all the elements affecting the cost in radial angiography and femoral angiography approaches, it is seen that TRA is a more expensive method compared to TFA. According to the study results, the element increasing the intervention cost in radial angiography arises out of expenses for consumables parallel with the expert opinions. Catheters preferred in radial angiography and femoral angiography differs. It is observed that catheter diameter used in radial angiography is narrower and it is more expensive.

Another cost element differing in terms of costs in radial and femoral angiography is determined to be the medicine expenses. Although this difference is not statistically considered to significant, it is considerable in terms of TRA approach. Brassalet et al (2008; 63-70) have examined 420 diagnostic (coronary angiography) and therapeutic interventions applied by four cardiologists in terms of exposure to radiation by using dosimetry of the specialists. Significant radiation effect has been observed in the use of radial artery compared to femoral artery. Radiation fallout in radial and femoral artery use for coronary angiography has been respectively to be $29 \mu \mathrm{Sv}$ (distribution 1-195) and $13 \mu \mathrm{Sv}$ (distribution 1-164) (p<0.0001) and in therapeutic intervention, it has been respectively measured $69.5 \mu \mathrm{Sv}$ (distribution 4-531) and 
$41 \mu \mathrm{Sv}(2-360)(\mathrm{p}=0.018)$. Also, fluoroscopy and intervention period have apparently prolonged in radial way. Thus, in spite of specific protective precautions, dose level seems to be the most important factor to limit the use. In terms of the amount of radiopaque matterial used during coronary angiography intervention, it is stated that there is a difference in radial angiography. When it is considered in parallel with the expert opinions, it can be explained with the use of more radiopaque matterial during TRA compared to TFA and it may be considered as an element increasing the cost and it is required to be taken into consideration in terms of exposure to more radiation.

\section{CONCLUSION}

According to the cost minimisation analysis results of Transradial and Transfemoral coronary angiography interventions in terms of financial costs, it can be said that TRA approach is a more expensive method than TFA approach in terms of the average total cost per patient.

On the other hand, studies in the literature show that Transradial approach is a safer alternative compared to femoral catheterization in terms of factors such as early mobilization, lower bleeding complication, and shorter hospitalization even though it results in lower intervention success, longer radiation time, and higher contrast volume.

Considering these results, conducting cost-effectiveness study for TRA and TFA is effective in decision-making for specialists and shall ensure that both costs and results of the intervention are to be taken into consideration. 


\section{REFERENCES}

Agostoni, P., Biondi-Zoccai, G.G., De Benedictis, M.1., Rigattieri S, Turri, M., Anselmi, M., (2004). Radial versus femoral approach for percutaneous coronary diagnostic and interventional procedures; Systematic overview and meta-analysis of randomized trials. Journal of the American College of Cardiology 44:349356.

A ̆gırbaş, İ. (2014). Financial Management and Cost Analysis in Health Institutions. Siyasal Press, Ankara

Aktürk, E., Kurtoğlu, E., Ermiş, N., Açıkgöz, N., Yağmur, J., Altuntaş, M.S., Pekdemir, H., Özdemir, R. (2014). Comparision of pain levels of transradial versus transfemoral coronary catheterization: a prospective and randomize dstudy. Anadolu Kardiyoloji Dergisi 2014; 14: 140-6

Bertrand, O.F., Rao, S.V., Panchol,Y.S., Jolly, S.S., Rodés-Cabau, J., Larose, E., (2010). Trans radial approach for coronary angiography and interventions: results of the first international transradial practice survey. JACC Cardiovasc Interv 3:1022-1031.

Brasselet, C., Blanpain, T., Tassan-Mangina, S., Deschildre, A., Duval, S., Vitry, F., Gaillot-Petit, N., Clément, J.P., Metz, D. (2008). Comparis on of operatör radiation exposure with optimized radiation protection devices during coronary angiograms and ad hoc percutaneous coronary interventions by radial and femoral routes. European Heart Journal 29:63-70.

Caputo, R.P., Tremmel, J.A., Rao, S., Gilchrist, I.C., Pyne, C., Pancholy, S. (2011). Transradial arterial Access for coronary and peripheral procedures: executive summary by the Transradial Committee of the SCAI. Catheterization and Cardiovascular Interventions.78:823-839.

Çelik, Y. (2013) Health Economy. Siyasal Press, Ankara

Kiemeneij, F., Laarman, G.J. (1993). Percutaneous transradial artery approach for coronary stent implantation. Catheterization and Cardiovascular Diagnosis Journal 30:173-8.

Louvard, Y., Lefevre, T., Morice, M.C. (1997). Radial approach: what about the learning curve? Catheterization and Cardiovascular Diagnosis Journal 42: 467-468.

Noto, T.J., Johnson, L.W., Krone, R., Weaver, W.F., Clark, D.A., Kramer, J.R., Verrovec, G.W., Parker, J.J. (1991). Cardiac catheterization 1990: a report of the Registry of the Society for Cardiac Angiography and Interventions. Catheterization and Cardiovascular Diagnosis Journal; 24:75-83.

Tatar, M. (2013). Health Economy. Sur, H., Palteki, T., Hospital Management. İstanbul: Nobel Tip Bookstore; $337-54$.

TKD (Turkish Cardiology Association)(2005). Guide for capability in interventional cardiology, 33

Erişim Yeri: [http://www.tyih.gov.tr/]. Erişim tarihi: 15.05.2016

Ünal, S., Acar, B., Yayla, Ç., Balcı, M.M., Ertem, A.G., Kara, M., Maden, O., Temizhan, A., Tola, M., Balbay, Y. (2016). Manual Heating of Radial Artery to Facilitate Radial Puncture Prior to Transradial Coronary Catheterization: A Randomized, Double-Blind Clinical Trial. The BALBAY MANEUVER Study. The American Journal of Cardiology, 10-3

Yiğit, F., Sezgin, A.T., Erol, T., Demircan, F., Tekin, G., Katırcıbaşı, T., Tekin, A., Müderrisoğlu, H. (2006). An experience on radial versus femoral approach for diagnostic coronary angiog raphy in Turkey. Anadolu Kardiyoloji Dergisi 6; 229-34 